UDC 004.3

\title{
EVALUATION OF PRODUCTIVITY VIRTUALIZATION TECHNOLOGIES OF SWITCHING EQUIPMENT TELECOMMUNICATIONS NETWORKS
}

\author{
${ }^{1}$ Oleksandr I. Romanov, ${ }^{2}$ Mykola M. Nesterenko, ${ }^{2}$ Nadiia O. Fesokha, \\ ${ }^{1}$ Volodymyr B. Mankivskyi \\ ${ }^{1}$ Institute of Telecommunication Systems Igor Sikorsky Kyiv Polytechnic Institute, Kyiv, Ukraine \\ ${ }^{2}$ Military Institute of Telecommunications and Information Technologies, Kyiv, Ukraine
}

\begin{abstract}
Background. To date, the effectiveness of the use of virtualization technologies for the deployment of the organization's infrastructure of any complexity is beyond doubt. First of all, it is a gain due to the rapid deployment of the necessary infocommunication services, flexible scaling of the system without replacing the hardware server platform, which was purchased earlier and has a sufficient "estimated" resource. These approaches are commonly used by modern telecom operators to build their telecommunications networks or to expand the range of new services. In turn, the rapid development of virtualization technologies such as hypervisor-based technology for mutual isolation of virtual machines and container virtualization based on Docker, requires further research on the effectiveness of their use.
\end{abstract}

Objective. The aim of the article is to determine the effectiveness of container virtualization and virtual machines.

Methods. Creating a segment of the IP telephony network for testing the load of IP PBX (PBX) Asterisk on a virtual machine and container with test calls.

Results. The share of CPU usage when using Elastix IP-based PBX based on a virtual machine is higher by an average of $5 \%$ of the container. Instead, the use of RAM is very different. In the case of virtual machines, it is several tens of times larger, which will obviously affect the operation of the system as a whole.

Conclusions. The study showed that the use of IP PBX (PBX) Asterisk on a virtual machine compared to the container takes up more virtual server resources, but when loaded with simultaneous calls is less stable.

Keywords: virtual machine; container; IP telephony; container virtualization; virtualization.

\section{INTRODUCTION}

To date, the effectiveness of the use of virtualization technologies for the deployment of the organization's infrastructure of any complexity, no one doubts. First of all, it is a gain due to the rapid deployment of the necessary infocommunication services, flexible scaling of the system without replacing the hardware server platform, which was purchased earlier and has a sufficient "estimated" resource. These approaches are commonly used by modern telecom operators to build their telecommunications networks or to expand the range of new services [1].

In turn, the rapid development of virtualization technologies such as hypervisor-based technology for mutual isolation of virtual machines and container virtualization based on Docker, requires further research on the effectiveness of their use.

One of the necessary services of the corporate network is the deployment of IP-telephony, which has also been widely implemented and has many integration software solutions. Today, one of the widely available and popular software solutions is IP PBX (PBX) Asterisk. This is due to the wide range of Asterisk functions and the modularity of the structure, which allows you to additionally connect modules written in many programming languages. It supports not only TCP / IP stack protocols, but also traditional telephony signaling protocols, ie provides the ability to use video, call encryption and call center functions, as well as all the main functions of a regular PBX - call recording, call statistics, voice menu and etc. Asterisk easily integrates with other communication systems, including traditional PBXs. One of the open source projects that used the Asterisk PBX IP core is Elastix, which has a userfriendly web management interface for administration [2].

\section{MAIN PART}

Let's take a closer look at the features of existing virtualization technologies for the deployment of a virtual infrastructure of communication operators (providers) for the provision of infocommunication services. The main types of virtualization are hardware (virtual machines) and container. It should be noted that for the rapid introduction of IPtelephony, it is advisable to use virtualization technologies in corporate and public call centers. Therefore, the question arises of choosing the type of virtualization that will be more rational when building a model of virtual infrastructure of IP telephony networks, depending on the capacity of existing network and server equipment. This should take into account such parameters as the speed of the virtual environment, the load on the hardware platform, ease of deployment and scaling of the system [2-4]. 
In turn, the virtual machine (Virtual Machine) provides complete emulation of the physical machine or runtime (for the program). Namely, guest operating systems (guest OS) and its applications share hardware resources from a single host server or from a pool of host servers. Each virtual machine requires its own OS, the hardware is accordingly virtualized (Virtual Hardware). A virtual machine hypervisor or monitor is firmware or hardware that creates and runs virtual machines. It is located between the host server and the virtual machines and is required for server virtualization (fig. 1)[5].

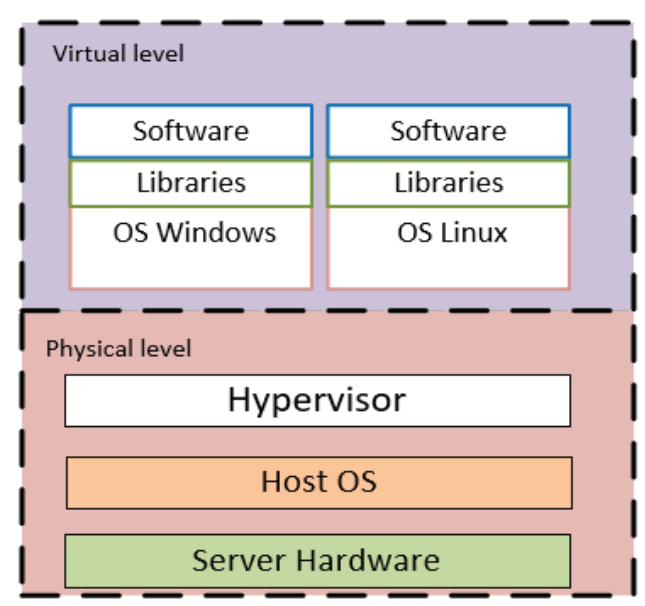

Fig.1. Implementation of virtual machines

However, virtual machines can take up a lot of system resources. Each virtual machine runs not only a complete copy of the operating system, but also a virtual copy of all the equipment that the operating system must perform. It quickly adds many RAM and CPU cycles. This is usually economical compared to running individual real computers (servers), but for some programs this process may be unnecessary.

The containers are located on top of the physical server and its operating system, usually Unix or Windows. Each container shares the core of the host system, usually executable files and libraries. Common components are read-only. Sharing OS resources, such as libraries, greatly reduces the need to play operating system code and means that the server can run multiple workflows (network services) when installing a single operating system. Containers, therefore, are extremely "light" - they can take up a megabyte in size and unfold in just a few seconds. On the contrary, running virtual machines can take minutes an order of magnitude longer than the equivalent container. Figure 2 compares the two architectures using virtual machines and container handling [6-8].
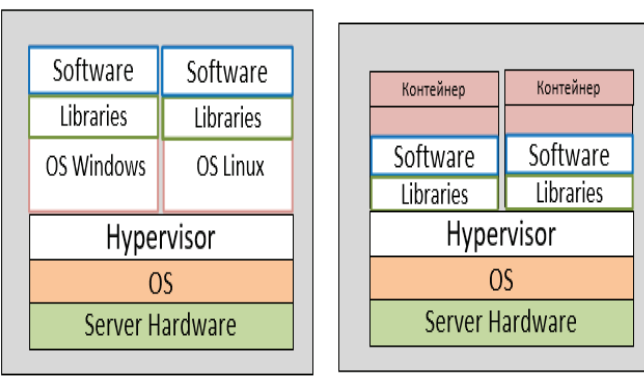

Fig.2. Comparison of virtual machines and containers

Unlike virtual machines, a container uses an operating system kernel that supports programs, libraries, and system resources to run a specific program (service). In practice, this means that you can host two to three times more applications on a single container server than you can with a virtual machine. In addition, with containers, you can create a portable, consistent operating environment for development, testing, and deployment [8].

Based on the above, to conduct a practical experiment and determine the effectiveness of IP ATC when using these virtualization technologies, a segment of the corporate network was built (fig. 3). Subsequently, on the basis of this virtual stand, testing was performed at different values of the input load.

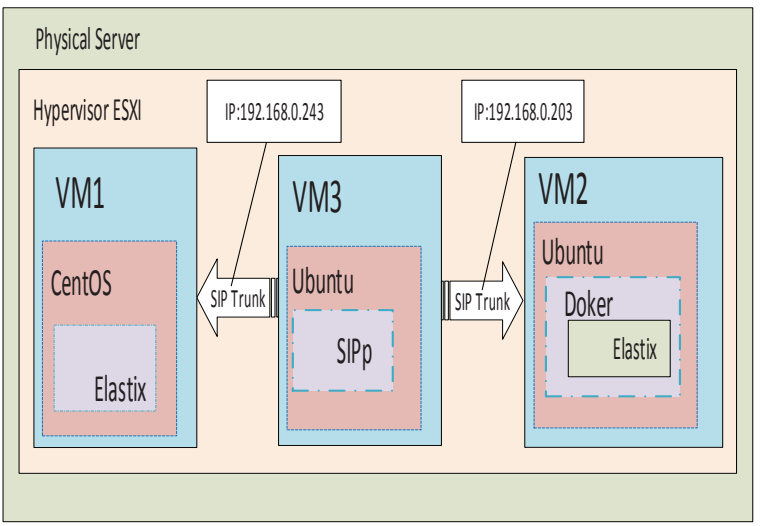

Fig.3. The main components of the virtual segment of IP-telephony based on virtual machines and containers

The physical server has a standalone ESXi hypervisor from VMware that does not require an operating system and is installed directly on the server hardware. Three virtual machines are deployed on the hypervisor.

1. The first virtual machine (VM1) has a CentOS distribution on which the Elastix IP PBX is deployed. That is, the Elastix IP PBX is deployed using virtual machine technology.

2. The second virtual machine (VM2) has Ubuntu Server OS with support for container processing. Based on this OS, Docker was deployed and a 
container was created in which the Elastix IP PBX was configured. That is, in this case, the IP PBX is created in the container.

3. On the third virtual machine (VM3) Ubuntu Desktop OS is installed on which the SIPp utility is installed, which allows to create a load on the Elastix IP PBX, namely to generate calls.

The SIPp utility is an open tool for testing and generating SIP protocol traffic. The advantage of this tool is the support of TLS, SIP authentication, conditional scripts, UDP retransmissions, regular expressions, the ability to insert arbitrary headers, logging, execution of system commands depending on the result [17].

Prior to testing, the resources used by the virtual machine with the Elastix IP PBX were removed using the Glances Monitor utility. As you can see in the figure below, the virtual machine generally uses a system-acceptable amount of RAM and a small amount of CPU. You should also note indicators such as VIRT virtual process size (shows the total amount of memory that the program is able to address at this time) and RES (shows how much physical memory the process uses) will differ (fig.4). The RES value will be less than the VIRT value, as most programs depend on the shared C library.

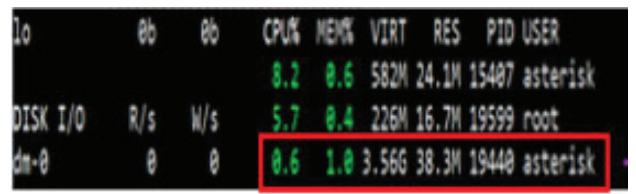

Fig.4. Statistics of resource use by a virtual machine IP-PBX Elastix (Asterisk)

The results of the analysis of the use of system resources by the container are presented in fig. 5 .

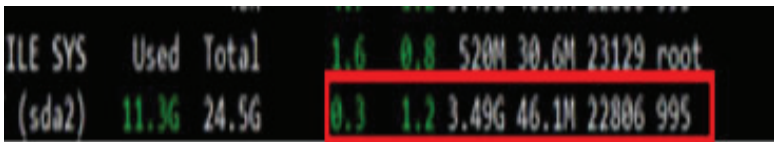

Fig.5. Elastix (Asterisk) IP PBX resource usage statistics

As you can see, the percentage of CPU usage is almost at the same level as when using virtual machine technology and container handling. In contrast, the use of RAM and RES (physical memory) in a virtual server is about $20 \%$ higher when using a container than in a virtual machine.

When creating a virtual communication channel, the following parameters were set (fig. 6.):

1. duration of calls (conversations), set by the key: -d 210 s (3.5 minutes);

2. the maximum number of simultaneous calls, set by the key: -1 500 (500 simultaneous calls);

3. maximum speed of calls per second, set by the key: -r 10 (not more than 10 calls / sec.).
4. the duration of the test was approximately 1 hour (3600 s).

In the future, only the number of simultaneous calls on SIP trunk changed, namely -1 700 (700 simultaneous calls) fig. 7 and $-1 \quad 950 \quad$ (950 simultaneous calls) fig. 8 .

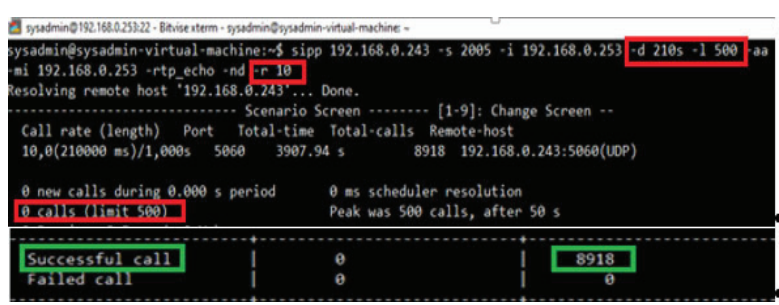

Fig.6. Results of SIPp configuration and IP-PBX testing Elastix (VM1) with 500 simultaneous calls

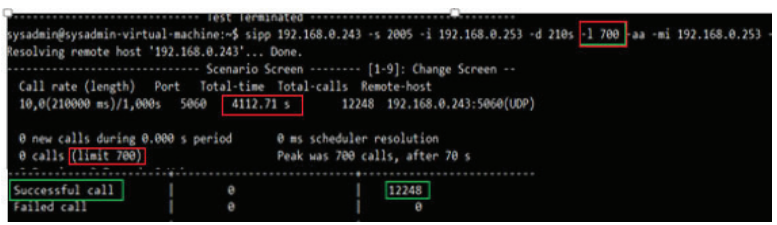

Fig.7. Results of SIPp configuration and IP-PBX testing Elastix (VM1) with 700 simultaneous calls

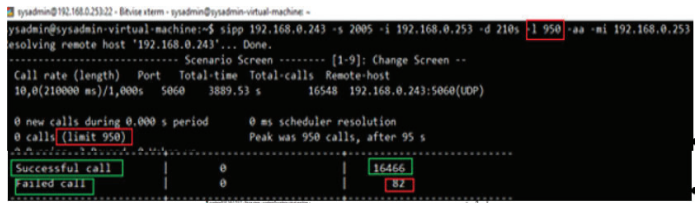

Fig.8. Results of SIPp configuration and IP-PBX testing Elastix (VM1) for 950 simultaneous calls

In fig. 9 shows the statistics obtained by the builtin means of monitoring the performance of IP-PBX Elastix, which also allows you to estimate the number of resources used under different conditions

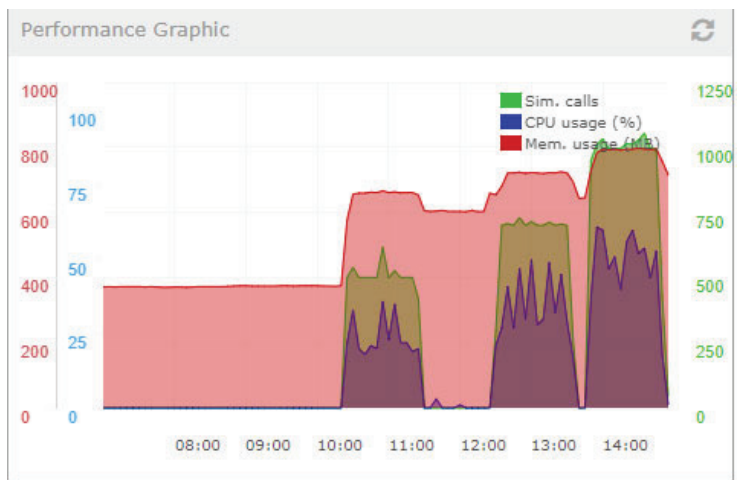

Fig.9. Results of servicing incoming calls and involved Elastix resources with built-in monitoring tools $(500,700,950$ simultaneous calls)

The test results allow us to conclude that when using IP-PBX Elastix on the basis of virtual machines with 500 simultaneous calls CPU load on average is $37 \%$ virtual RAM $640 \mathrm{MB}$, with 700 
simultaneous calls CPU load on average is 58\% virtual RAM $710 \mathrm{MB}$, with 950 simultaneous calls, the CPU load averages $69 \%$ of the virtual RAM of $800 \mathrm{MB}$. However, when 950 Elastix IP PBX calls are loaded, the virtual machine becomes more busy and not all calls are processed. The number of unprocessed calls varies around $1 \%$.

To test IP-PBX Elastix in container processing based on a virtual layout (Fig. 3) was also conducted an experiment with the same values of the input load. Namely, based on the above scenario, a communication channel was created between SIPp (VM3) and Elastix IP PBX in the container (VM2) with the following parameters (fig. 10):

1. duration of calls: $-\mathrm{d} 210$ and (3,5 minutes);

2. maximum number of simultaneous calls: -1 500 (not more than 500);

3. maximum speed of calls per second: -r (not more than 10 calls / second);

4. the duration of the test is approximately 7 minutes.

In the future, only the number of simultaneous calls on SIP trunk changed, namely -1 700 (700 simultaneous calls) fig. 12 and $-1 \quad 950 \quad$ (950 simultaneous calls) fig. 14.

In fig. $11,13,15$ the statistics received by means of monitoring of productivity of IP-automatic telephone exchange of Elastix which allows to estimate also quantity of the used resources under various conditions are resulted.

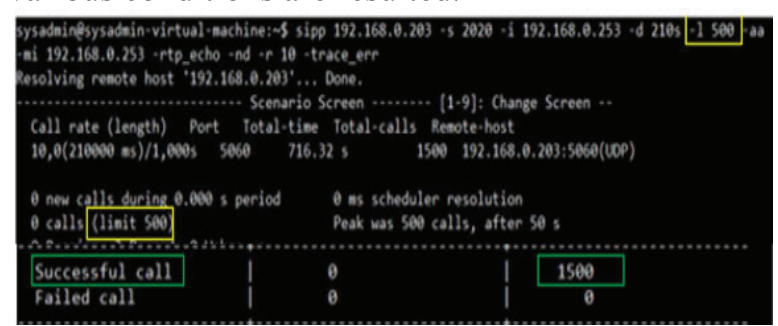

Fig.10. Results of setting up SIPp and testing a container with Elastix IP PBX with 500 simultaneous calls
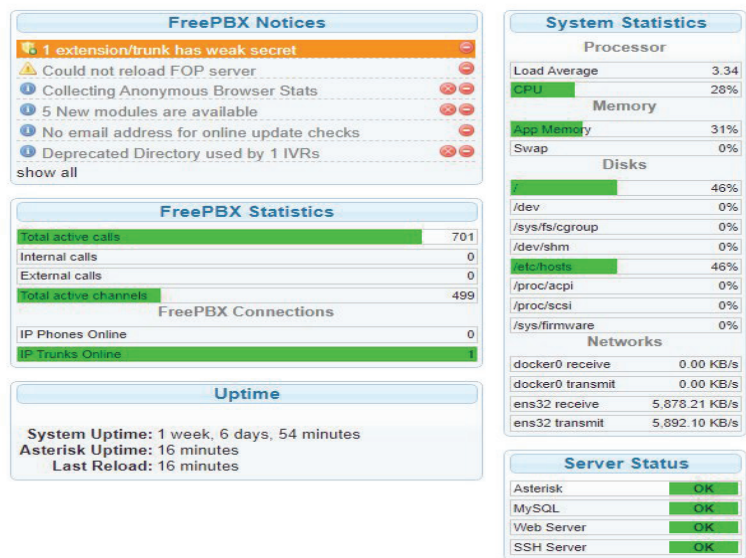

Fig.11. The results of the resources involved in the container IP-PBX Elastix for 500 simultaneous calls

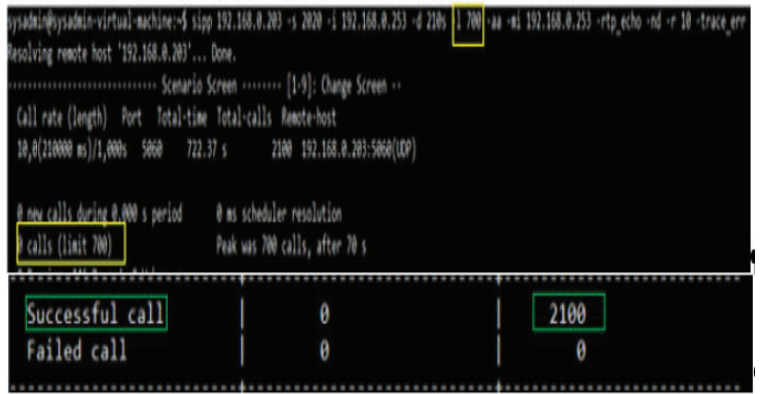

Fig.12. Results of setting up SIPp and testing a container with an Elastix IP PBX with 700 simultaneous calls
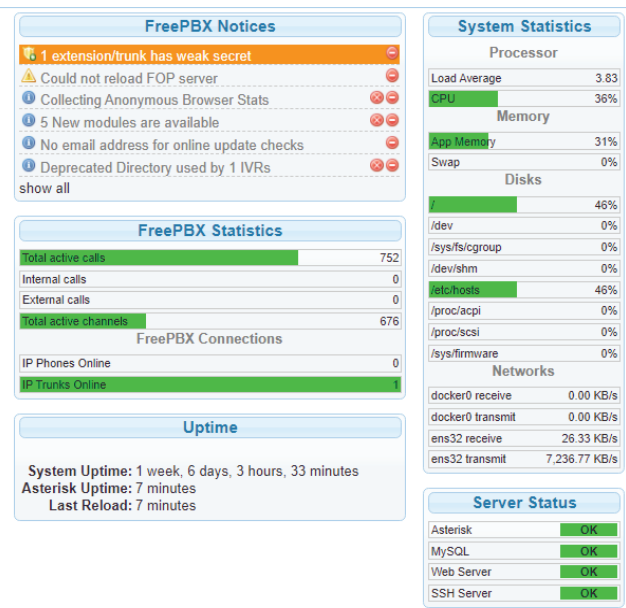

Fig.13. The results of the resources involved in the container IP-PBX Elastix for 700 simultaneous calls

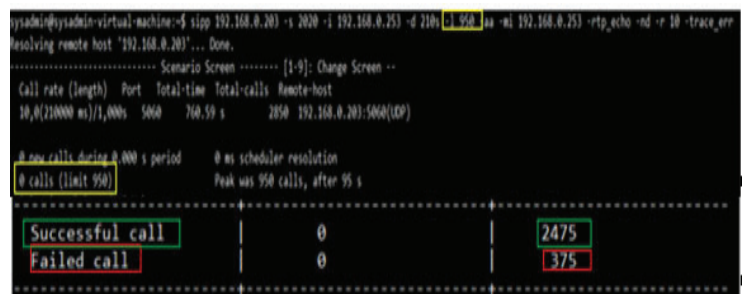

Fig. 14. Results of setting up SIPp and testing the container with Elastix IP PBX for 950 simultaneous calls 


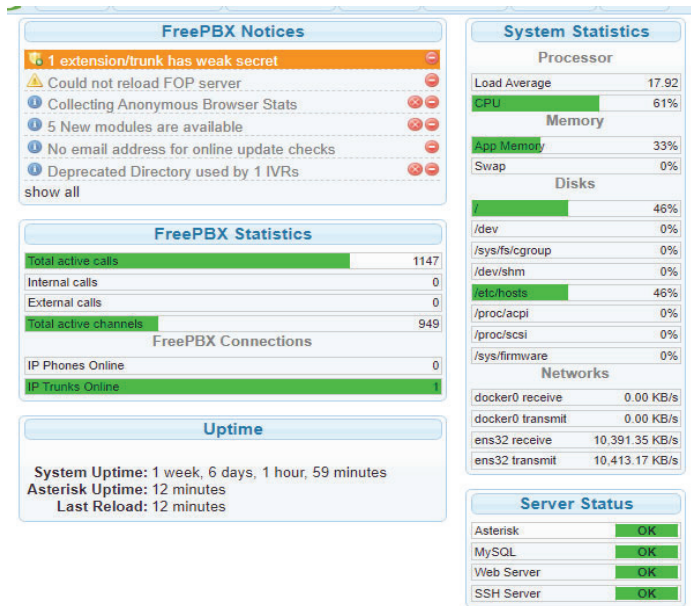

Fig.15. The results of the resources involved in the container IP-PBX Elastix for 950 simultaneous calls

The test results suggest that using Elastix container-based IP PBX: with 500 simultaneous calls, the CPU load averages $28 \%$, virtual RAM is loaded by approximately $31 \%$; with 700 simultaneous calls, CPU usage averages 33\% of virtual RAM is approximately $31 \%$ loaded; with 950 simultaneous calls, the CPU load averages $61 \%$ of virtual RAM is about $33 \%$ full. However, when 950 Elastix container-based PBX calls are loaded, the number of unserved calls increase compared to virtual machine technology and is 13\% (under these experimental conditions).

\section{CONCLUSIONS}

From the results it can be noted that the share of CPU use when using Elastix IP-PBX based on a virtual machine is higher by an average of $5 \%$. Instead, the use of RAM is very different. In the case of virtual machines, it is several tens of times larger, which will obviously affect the operation of the system as a whole. When evaluating the performance of an

I / O system, containers are more productive than virtual machines in terms of execution speed and number of transactions. The performance of virtual machines deteriorates significantly when scaled, which is less optimal compared to containers, where performance remains fairly constant with increasing numbers.

To sum up, containers offer better performance when implementing Elastix, performing more read and write operations. However, when Elastix IPbased PBX is fully loaded on a virtual machine (950 simultaneous calls), it is more stable than containerbased and has fewer rejected connections.

\section{REFERENCES}

1. Romanov OI, Nesterenko MM, Fesokha NO Analysis of modern virtualization technologies for the construction of information and telecommunication systems // Collection of scientific works of VITI. - Kiev, 2019. - Issue. №1 - P. 82-90.

2. Gordievsky VM The essence, structure and classification of modern virtualization technologies [Electronic resource] - Access mode: http://shgpi.edu.ru/files/nauka/vestnik/2015/2015-125.pdf.

3. Robar A. FreePBX 2.5 Powerful Telephony Solutions [Electronic resource] - Access mode: http://asterisk-service.com/FreePBX-2.5.

4. Colman Carpenter David Duffett Nick Middleton. Ian Plain Asterisk 1.4 The Professional's Guide. [Electronic resource] - Access mode: http://asteriskservice.com/page/asterisk-books

5. Globa L., Skulysh M., Romanov O., Nesterenko M. (2018, November). Quality control of mobile communication management services in a hybrid environment. In the International Conference on Information and Telecommunication Technologies and Radio Electronics (pp. 76-100). Springer, Cham. Springer Publishing House, Cham.

6. About hypervisors, system virtualization and how it works in a cloud environment. [Electronic resource] Access mode: https://www.ibm.com/developerworks/ru/library/clhypervisorcompare.

7. Skulish MA, Romanov OI, Nesterenko MM The principle of forecasting the necessary virtual resource of the cloud system for the mobile operator // Collection of scientific works of VITI. - Kiev, 2018. - Issue. №2 - P. $113-119$.

8. Фecëxa H.O. Analysis of software and hardware approaches to system virtualization // Proceedings of the XI scientific-practical conference VITI. - Kiev, 2018. Issue №2. - p.225-226.

9. 16. Docker user guide [Electronic resource] URL: https://docs.docker.com/userguide.

10. J. E. Smith, and R. Nair, "The Architecture of Virtual Machines," Computer, vol. 38, no. 5, pp. 32-38, 2005.

11. Y. Li, W. Li, and C. Jiang, "A Survey of Virtual Machine System: Current Technology and Future Trends", in Proceedings of the Third International Symposium on Electronic Commerce and Security 2010.

12. Gustavo AA Santana. Fundamentals of data center virtualization: understanding methods and constructs 2013.

13. J. E. Smith, and R. Nair, "The Architecture of Virtual Machines," Computer, vol. 38, no. 5, pp. 32-38, 2005.

14. S. Nanda, and T. Chiueh, "A Survey on Virtualization Technologies", Experimental Computer Systems Lab, SUNY Stony Brook, SUNY RPE Report TR-179, 2005.

15. Aladyshev OS, Baranov AV, son Yonin, RP, Kiselyov EA, Orlov VA Comparative analysis of options for deploying software platforms for high-performance computing // Bulletin of the UGATU. 2014. T. 18, № 3, p. 295-300. URL: http://journal.ugatu.ac.ru/index.php/vestnik/article/view/1 $101 / 945$

16. Helsley M. LXC: Linux container tools [Electronic resource] 
http://www.ibm.com/developerworks/linux/library/l-lxccontainers/1-lxc-containers-pdf.pdf.

17. Opportunities Asterisk. Atserisk load testing 1.8. Utility sipp. [Electronic resource]. Access mode: https://voxlink.ru/kb/asterisk-configuration/asterisk-testsipp

Романов О.І., Нестеренко М.М., Фесьоха Н.О., Маньківський В.Б.

Оцінка продуктивності технологій віртуалізації комутаційного обладнання телекомунікаційних мереж

Проблематика. На теперішній день ефективність використання технологій віртуалізації для розгортання інфраструктури організації будь-якої складності ні в кого не викликає сумніву. В першу чергу, це виграш за рахунок швидкого розгортання необхідних інфокомунікаційних сервісів, гнучке масштабування системи без заміни апаратної серверної платформи, яка була закуплена раніше та має достатній «розрахунковий» ресурс. Звичайно дані підходи широко використовуються сучасними операторами зв'язку при побудові своїх телекомунікаційних мереж або для розширення спектру надання нових послуг.

В свою чергу бурхливий розвиток технологій віртуалізації таких як: технологія на основі гіпервізора для взаємної ізоляції віртуальних машин та контейнерної віртуалізації на основі Docker, вимагає додаткового дослідження щодо ефективності їх використання.

Мета дослідження. Метою статті є визначення ефективності використання контейнерної віртуалізації та віртуальних машин.

Методика реалізації. Створення сегменту мережі IP-телефонії для проведення тестування навантаження IP ATC (PBX) Asterisk на віртуальній машині та контейнері тестовими дзвінками.

Результати дослідження. Частка використання CPU при використанні IP-ATC Elastix на основі віртуальної машини більша в середньому на 5 \% від контейнера. Натомість використання оперативної пам'яті різко відрізняється. У випадку віртуальних машин вона більша в декілька десятків разів, що не може не позначитися на роботу системи в цілому.

Висновки. Проведене дослідження показало, що використання IP ATC (PBX) Asterisk на віртуальній машині в порівнянні 3 контейнером займає більше віртуальних ресурсів серверу але при навантаженні одночасними викликами менш стабільна.

Ключові слова: віртуальна машина; контейнер; IP-телефонія; контейнерна віртуалізація; віртуалізація.

Романов А.И., Нестеренко Н.Н., Фесьоха Н.А., Маньковский В.Б.

Оценка производительности технологий виртуализации коммутационного оборудования
телекоммуникационных сетей

Проблематика. В настоящее день эффективность использования технологий виртуализации для развертывания инфраструктуры организации любой сложности ни у кого не вызывает сомнения. В первую очередь, это выигрыш за счет быстрого развертывания необходимых инфокоммуникационных сервисов, гибкое масштабирование системы без замены аппаратной серверной платформы, которая была закуплена ранее и имеет достаточный «расчетный» ресурс. Обычно данные подходы широко используются современными операторами связи при построении своих телекоммуникационных сетей или для расширения спектра предоставления новых услуг.

В свою очередь бурное развитие технологий виртуализации как: технология на основе гипервизора для взаимной изоляции виртуальных машин и контейнерной виртуализации на основе Docker, требует дополнительного исследования по эффективности их использования.

Цель исследования. Целью статьи является определение эффективности использования контейнерной виртуализации и виртуальных машин.

Методика реализации. Создание сегмента сети IP-телефонии для проведения нагрузочного тестирования IP ATC (PBX) Asterisk на виртуальной машине и контейнере тестовыми звонками.

Результаты исследования. Доля использования CPU при использовании IP-ATC Elastix на основе виртуальной машины больше в среднем на 5\% от контейнера. Зато использование оперативной памяти резко отличается. В случае виртуальных машин она больше в несколько десятков раз, что не может не сказаться на работе системы в целом.

Выводы. Проведенное исследование показало, что использование IP ATC (PBX) Asterisk на виртуальной машине по сравнению с контейнером занимает больше виртуальных ресурсов сервера но при нагрузке одновременными вызовами менее стабильна.

Ключевые слова: виртуальная машина; контейнер; IP-телефония; контейнерная виртуализация; виртуализация. 